Albada, A., Vernooij, M., Osch, L. van, Pijpe, A., Dulmen, S. van, Ausems, M.G.E.M. Does and should breast cancer genetic counselling include lifestyle advice? Familial Cancer: 2014, 13(1), 35-44

\begin{tabular}{|l|l|}
\hline $\begin{array}{l}\text { Postprint } \\
\text { Version }\end{array}$ & 1.0 \\
\hline Journal website & $\underline{\text { http://link.springer.com/article/10.1007\%2Fs10689-013-9672-5 }}$ \\
\hline Pubmed link & $\underline{\text { http://www.ncbi.nlm.nih.gov/pubmed/23934600 }}$ \\
\hline DOI & $10.1007 /$ s10689-013-9672-5 \\
\hline
\end{tabular}

This is a NIVEL certified Post Print, more info at http://www.nivel.eu

\title{
Does and should breast cancer genetic counselling include lifestyle advice?
}

\author{
AKKE ALBADA • MADELE`N VERNOOIJ • LIESBETH VAN OSCH • ANOUK PIJPE • SANDRA VAN \\ DULMEN • MARGREET G. E. M. AUSEMS
}

\begin{abstract}
To optimally inform counselees about their and their relatives' risks, information about lifestyle risk factors, e.g. physical activity and alcohol consumption, might be discussed in breast cancer genetic counselling. This study explored whether lifestyle was discussed, on whose initiative, whether information and/or advice was given, and whether discussion of lifestyle was related to counselees' characteristics and their causal attributions. First and follow-up consultations with 192 consecutive counselees for breast cancer genetic counselling were videotaped and coded for discussion of lifestyle topics. Counselees completed web-based questionnaires before the initial and after the final consultation. With 52 (27\%) counselees lifestyle was discussed, either in the first, or the final consultation, or both. Counselees mostly raised the topic (60\%). Counsellors provided information about lifestyle risk factors to $19 \%$ and lifestyle advice to $6 \%$ of the counselees. Discussion of lifestyle was not associated with counselees' characteristics or causal attributions. Postcounselling, more affected counselees considered lifestyle as a cause of their breast cancer (29\%) compared to pre-counselling (15\%; $\mathrm{p}=0.003$ ). Information and advice about lifestyle risk factors was infrequently provided, both with breast cancer unaffected and affected counselees and with those who did and did not consider their lifestyle as a cause of their breast cancer. Modifiable lifestyle factors could be discussed more frequently to optimally inform counselees about possible ways to reduce their risk. Counsellors should be educated about effects of lifestyle and research should be conducted on how to best integrate lifestyle information in breast cancer genetic counselling.
\end{abstract}


Albada, A., Vernooij, M., Osch, L. van, Pijpe, A., Dulmen, S. van, Ausems, M.G.E.M. Does and should breast cancer genetic counselling include lifestyle advice? Familial Cancer: 2014, 13(1), ) 35-44

\section{INTRODUCTION}

Genetic counselling is available for individuals with a (family) history of breast cancer (BC) who wish to learn about their own or their relatives’ risk to develop BC (again). BC genetic counselling aims to help counselees to make well informed decisions about surveillance and to increase feelings of personal control [1]. The most important motives for women with a family history of BC to attend BC genetic counselling are to receive information about their risk, about early detection and about how to prevent BC [2-4]. Counsellors provide surveillance advice and discuss possibilities for prophylactic surgery if indicated [5].

As BC is a multifactorial disease, both genetic and non- genetic factors are involved in its development [6]. Mutations in known high-risk genes (BRCA1/2), account for less than $5-10 \%$ of $\mathrm{BC}$ in the general population $[7,8]$. Around

$27 \%$ of female BCs are thought to be linked to lifestyle and environmental factors [9]. Lifestyle factors like exercise and weight control currently are among the few modifiable risk factors which give women the opportunity to reduce the risk of BC [10]. Among women from the general population, moderate physical exercise is associated with a decrease in BC risk of 20-40 \% [11-13] and a high BMI is associated with a significant increase in post-menopausal risk [12, 14]. Current use of oral contraceptives slightly increases the risk of BC with a relative risk of 1.30 [15], but decreases the lifetime risk of ovarian cancer. Alcohol use increases the relative risk with $7 \%$ per glass a day [16]. Breastfeeding confers a protective effect of $4 \%$ decrease per year breast feeding [17]. With regard to diet, saturated fat intake might slightly increase risks, but research has been too limited to draw a conclusion $[10,14]$. Smoking has little or no independent effect on BC risk [16]. The few studies that have appeared yet on the influence of lifestyle on BC risk among women at increased risk [18] or with a BRCA1/2 gene mutation indicate that a healthy lifestyle was associated with older age at onset and lower lifetime risks [19-25]. Among $\mathrm{BC}$ genetic counselees there is confusion and uncertainty about the associations between health behaviours and BC risk [26, 27]. Understanding how risk factors are linked to the disease might give them a feeling of control over the disease [28] and may motivate them to make well- informed decisions about health behaviours [29]. It is unknown whether counsellors provide information about the protective effect of a healthy lifestyle. The influence of lifestyle could be discussed to optimally inform counselees about their own and their relatives' risks, especially if they feel the need to do something to reduce their risk.

The UK familial BC guideline states that BC genetic counselling is an opportunity for a woman to better under- stand the contribution of family history and lifestyle con- cerning her risk of BC. Furthermore, it states that all women should receive information about lifestyle risk factors, such as diet and alcohol [29]. The USA BC risk reduction guideline also includes discussion of lifestyle risk factors (alcohol, exercise and weight control) and recommends that risk reduction options, amongst others lifestyle changes, should be discussed in a shared decision making environment [30]. The Australian guideline for advice about familial aspects of BC includes discussion of modifiable risk factors, such as adult weight gain, diet and alcohol [31]. The Dutch BC guidelines do not include a recommendation to provide information about lifestyle risk factors except for the notion that women from BRCA1/2 families may consider other contraception than oral contraceptives [5, 32]. 
Albada, A., Vernooij, M., Osch, L. van, Pijpe, A., Dulmen, S. van, Ausems, M.G.E.M. Does and should breast cancer genetic counselling include lifestyle advice? Familial Cancer: 2014, 13(1), ) 35-44

To explore lifestyle discussion in BC genetic counsel- ling, this study aims to answer three research questions:

1. .How often are lifestyle risk factors (i.e. physical activity, diet, alcohol, smoking, contraceptives and breast feeding) discussed in BC genetic counselling, either as information or advice and on whose initiative was the topic raised?

2. What is the association between lifestyle discussion and counselees' age, having children, disease status, education and BC risk and (for BC affected counselees only) with their attributions of the cause of their disease?

3. What are the pre to post-counselling changes in affected counselees' attributions regarding lifestyle and heredity as causes of their BC and are these influenced by whether lifestyle was discussed?

Given the absence of lifestyle topics in the Dutch BC guideline, we expect that lifestyle advice will not frequently be provided. We expect that if lifestyle is discussed this is mostly on the counselees' initiative, because some counselees may perceive their lifestyle as a possible cause of their own or their relatives' BC [33]. Initiation of discussion on lifestyle factors by counselees and the possibility to alter it might give them a feeling of control; this may be especially true for unaffected counselees [26]. Possibly, lifestyle is less often discussed with BC affected counselees because counsellors are afraid to induce feelings of guilt for the disease [34]. If lifestyle is not discussed then no changes in counselees' causal lifestyle attributions for BC are expected.

\section{METHODS}

The present study was conducted as part of a larger study on BC genetic counselling at the department of Medical Genetics of the University Medical Centre Utrecht. The procedure was described earlier [35]. The study was approved by the medical ethical committee of the hospital. All BC genetic counselees were approached for participation from February 2008 to April 2010. Female adult counselees who were the first of their (first degree) family to seek BC genetic counselling were included. Counselees were ineligible when a BRCA1/2 gene mutation was already identified in a relative or if they lacked internet access $(n=24)$. All consecutive eligible counselees $(n=336)$ received information about the study and 197 participated (response rate $58.6 \%$ ). Half of the decliners indicated a reason $(n=70 ; 50.4 \%)$, most did not want to participate because consultations were videotaped $(n=46)$. There were no significant differences between respondents and non-respondents in age and disease history. All fourteen BC genetic counsellors participated and recorded their consultations with 4-29 counselees. Three were clinical geneticists, five were residents and six were genetic counsellors (three in training).

\section{Videotaped consultations}

The consultations were recorded with the camera directed at the counsellor. Due to a logistic or technical failure five first consultations were not videotaped and these counselees were excluded from all analyses, resulting in 192 counselees. All counselees had an initial consultation and almost half of counselees (94) had a 
Albada, A., Vernooij, M., Osch, L. van, Pijpe, A., Dulmen, S. van, Ausems, M.G.E.M. Does and should breast cancer genetic counselling include lifestyle advice? Familial Cancer: 2014, 13(1), ) 35-44

follow-up consultation 3-6 months later. Six counselees had a second consultation before their final consultation, this intermediate consultation was not taken into account. All first and final consultations were coded by research assistants for discussion of lifestyle (yes/no), who had raised the topic of lifestyle for the first time (counsellor/counselee) and which topics were addressed (physical activity, diet, alcohol, smoking, contraceptives and breastfeeding or lifestyle in general). Additionally, we defined whether the communication style of the counsellor was advisory, e.g. 'you could consider drinking less alcohol' and/or informative e.g. 'drinking alcohol may increase the risk of BC' or neither. We fol- lowed the definition of information and advice of the Roter Interaction Analysis System (RIAS) [36] which considers utterances as information even if the counsellor said that there was a lack of evidence about the relation between lifestyle and BC risk. The first consultations were coded by two coders and the final consultations were coded by two other coders. Thirteen percent of the first consultations and

$7 \%$ of the final consultations were coded by both coders. Interrater agreement in the first consultations was $80.0 \%$ for whether lifestyle was discussed, $64.7 \%$ for whether the counsellor provided information and $70.6 \%$ for whether he/she provided advice. Interrater agreement in the final consultations was $85.7 \%$ for whether lifestyle was dis- cussed and $100 \%$ for whether information and/or advice were given. Additionally, for the first consultations a short summary of what was discussed concerning lifestyle was written by the coders. Because of the relatively low $(64.7 \%)$ agreement on whether information was provided in the first consultations, all information codes in these consultations were checked based on the summary.

\section{Counselee questionnaires}

Counselees completed a web-based questionnaire before the initial consultation and after the final consultation. Age, whether counselees had children and educational attainments were collected in the first questionnaire. All but the latter were derived from the medical file if missing. Causal attributions for developing BC were assessed in $\mathrm{BC}$ affected counselees in both questionnaires with items from The Revised Illness Perception Questionnaire (IPQ-R) [37]. The question concerning causal attributions of the IPQ-R was focused on breast cancer as performed by Van Oostrom et al. [38]. This question was: "What is according to you the cause of your breast cancer?', All 18 items of the validated Dutch IPQ-R were included. These items were amongst others: 'heredity, it's in the family', 'diet or eating habits', 'alcohol' and 'smoking'. Items were completed on a Likert scale ( $1=$ totally disagree to $5=$ totally agree). Items were recoded to (totally) disagree or no opinion (0) and (totally) agree (1). One variable was created for whether at least one of the variables alcohol, smoking or diet was seen as a cause.

\section{Counsellor questionnaire and medical files}

In a questionnaire after the final consultation, counsellors filled in the lifetime risk of developing BC for BC unaffected counselees as estimated with Claus tables and the Claus extended formula as integrated in the Dutch guide- lines [39] on a scale from 0 
Albada, A., Vernooij, M., Osch, L. van, Pijpe, A., Dulmen, S. van, Ausems, M.G.E.M. Does and should breast cancer genetic counselling include lifestyle advice? Familial Cancer: 2014, 13(1), ) 35-44

to $100 \%$. This estimate was extracted from the medical file if missing or if revised after the final visit. For affected counselees, the lifetime risk for the first degree female relatives (daughters, sisters, mother) to develop BC was assessed on a similar scale. The disease status, referral pathway and whether there was an indication for DNA-testing were derived from the medical file. The latter was unclear in the medical file of three counselees and was therefore based on what the counsellor had filled in on the questionnaire.

\section{Data analyses}

Analyses were conducted with Stata 12. Descriptive statistics were used to answer the first research question. With regard to the second research question, v2 tests were con- ducted for bivariate comparisons. Furthermore, multilevel logistic regression analyses were performed with discussion of lifestyle (yes/no) as dependent variable for BC affected and unaffected counselees separately. Independent variables were age, having children, education and lifetime risk of BC for the counselee. Because the risk to develop BC again was usually not discussed with BC affected counselees, for analyses with this group the risk for female first degree relatives (FDR) was used. For affected counselees an additional variable reflected whether at least one of the variables alcohol, smoking and diet or heredity was seen as cause of their BC (yes/no). For the third research question, a Chi squared test was conducted to compare the pre- and post counselling causal lifestyle attribution. To check whether the discussion of lifestyle was associated to the post counselling causal lifestyle attribution, a multi- level logistic regression was performed with the postcounselling causal attribution as dependent and the base- line causal attribution, lifestyle discussion (yes/no) and the BC risk for female FDR as independent variables. The multilevel logistic regression analyses were conducted with random intercept at the counsellor level (xtlogit). A multilevel model was chosen because counselees were nested within counsellors. Counselees were grouped based on who the counsellor of their first consultation was and the final consultations were mostly performed by the same counsellor ( $n=88$ of 94). The variance at the counsellor level on whether lifestyle was discussed was small (ICC $=3 \%$ ).

\section{RESULTS}

The mean lifetime BC risk for counselees unaffected with BC was $18.4 \%$ (Table 1). $55 \%$ of the BC unaffected counselees were at lower than $20 \%$ lifetime BC risk as estimated by the counsellor (not in table). Because the risk to develop BC again was not always discussed with $\mathrm{BC}$ affected counselees, for this group the lifetime risk for female FDR is given (mean $=20.9 \%$ ). For $45 \%$ of the BC affected counselees the risk for their FDR was estimated as lower than $20 \%$. For $78.7 \%$ of the counselees there was an indication for DNA-testing for themselves or a relative. DNA-test results revealed that seven counselees were BRCA1/2 carrier (all affected with BC at first consultation) and three counselees had a relative who was a carrier and they consequently received higher BC risk estimations. For other counselees no BRCA1/2 mutation was detected and their risk estimations were based on the personal medical and cancer family history.

With 52 (27.1\%) of the counselees lifestyle risk factors were discussed, either in the first $(n=42)$ or the final consultation $(n=14)$ or in both $(n=4$; Table 2$)$. With 
Albada, A., Vernooij, M., Osch, L. van, Pijpe, A., Dulmen, S. van, Ausems, M.G.E.M. Does and should breast cancer genetic counselling include lifestyle advice? Familial Cancer: 2014, 13(1), ) 35-44

counselees who had more than one consultation ( $\mathrm{n}=94)$, lifestyle was not nivel significantly more often discussed in their first compared to their final consultation $(\chi 2=0.71 ; p=0.40)$. Counselees initiated the topic of lifestyle in a majority of cases (59.6\%; Table 2). When lifestyle was discussed, the counsellor had most often provided information about lifestyle risk factors (36;18.8 \%) and less often advice about what lifestyle behaviours are protective or harmful (11;6 \%). With 14 counselees $(7 \%)$ the topic of lifestyle was raised but neither information nor advice were given by the counsellor. In these cases the counsellor for example asked if a relative with lung cancer had smoked when relevant for the estimation of whether cancer in the family was hereditary. In few other cases $(n<5)$ the counselee initiated the topic of lifestyle and the counsellor did not further address this topic. When lifestyle was addressed, on average 1.4 (SD $=0.97)$ lifestyle risk factors were discussed. Smoking, diet and the use of contraceptives were discussed most often. Information was often phrased very general, e.g.: 'I cannot give you specific lifestyle recommendations', and often did not reflect evidence regarding lifestyle risk factors, e.g.: 'There is no evidence for a relationship between lifestyle and BC'. Counsellors' advice was mostly a general recommendation for a healthy lifestyle, such as the advice to eat healthy.

There were no significant associations between discussion of lifestyle risk factors and counselees' disease status $(\chi 2=0.38 ; \mathrm{p}=0.54)$. Table 3 shows that lifestyle discussion was also not associated with counselee characteristics, such as BC risk. Also, lifestyle discussion with BC affected counselees was unrelated to their perception of lifestyle factors as a cause of their BC. Lifestyle was dis- cussed with four of the 11 counselees who considered lifestyle as a cause of their BC and this was not significantly more often than with other counselees $(\mathrm{OR}=2.16$; $\mathrm{p}=0.32$ ). These four counselees initiated the lifestyle discussion themselves.

Table 4 shows the causal attributions of BC affected counselees. Pre-counselling few counselees considered life- style factors as a cause for their disease (14.9\%), with diet as the most often mentioned factor. Post-counselling, a higher percentage of counselees $(28.8 \%$ ) considered lifestyle as a cause than pre-counselling ( $\chi 2=8.97$; $p$ $=0.003)$. Three out of the seven BRCA $1 / 2$ carriers considered lifestyle as one of the causes of their BC, both pre and post-counselling (Table 4). Post-counselling, all mutation carriers correctly considered heredity as a cause of their BC.

Table 5 shows that whether counselees regarded life- style as a cause postcounselling was not related to whether lifestyle was actually discussed during counselling ( $\mathrm{OR}=0.73 ; \mathrm{p}=0.67)$. The $\mathrm{BC}$ risk for FDR, which is communicated during counselling of $\mathrm{BC}$ affected counse- lees and indicates whether genetic factors may play a role, was a significant predictor of whether counselees thought that their $\mathrm{BC}$ was caused by hereditary factors $(\mathrm{OR}=1.30 ; \mathrm{p}=0.01)$.

\section{Discussion}

In this study we found that lifestyle behaviours were discussed with a quarter of counselees during BC genetic counselling and this was mostly initiated by the counselee. Brief general information about lifestyle risk factors for $\mathrm{BC}$ was given to less than $20 \%$ of the counselees. Discussion of lifestyle often concerned smoking or diet, whereas these factors are not convincingly related to BC risk [10,16]. Physical activity and alcohol consumption were less often discussed, while these are proven to influence BC risks. These findings confirm results from an Australian observational 
Albada, A., Vernooij, M., Osch, L. van, Pijpe, A., Dulmen, S. van, Ausems, M.G.E.M. Does and should breast cancer genetic counselling include lifestyle advice? Familial Cancer: 2014, 13(1), ) 35-44

study among a similar study population [40]. Additionally, our study suggests that lifestyle advice is rarely given and that counselee characteristics, such as BC risk, disease status, age and educational level, were not associated to whether lifestyle was discussed. Among counselees affected with BC, lifestyle risk factors were not more often discussed with counselees who considered their lifestyle as a cause of their BC than with those who did not indicate lifestyle as a cause of their BC.

\section{[TABLE 1]}

The active role of the counselee in raising the topic of lifestyle is exceptional given the counsellors' verbal dominance that has been consistently reported in BC genetic counselling studies [41, 42]. This may indicate that a larger number of counselees would have liked to address lifestyle, but did not see an opportunity to raise the topic. The observed lack of association between provision of lifestyle information and counselees' causal attribution extends findings of prior studies of BC genetic counselling that reported a lack of tailoring to counselees' needs and characteristics [41, 42]. Even though lifestyle was not routinely discussed with any subgroup of counselees considered, post-counselling more affected counselees considered lifestyle as a cause of BC than pre-counselling; this was unrelated to whether lifestyle was discussed. Other information sources than the genetic counselor, such as media, family, friends and other health care providers might have suggested lifestyle as an alternative cause for breast cancer. Possibly, counselees have concluded that if their BC is not primarily caused by genetic factors, as was indicated by the genetic counselling results for most counselees, other factors, like lifestyle risk factors, must have contributed to their disease.

\section{[TABLE 2] [TABLE 3]}

Furthermore, it seems that lifestyle is less frequently discussed in Dutch than in Australian BC genetic counselling and this might be due to the absence of lifestyle risk information in Dutch guidelines. In Australian first consultations information about health-protective behaviours was provided in almost half of the consultations and this was guided by the national guideline [40]. A comparison with BC genetic counselling in the USA is not possible as the frequency of lifestyle information was not reported in process studies [43-45]. However, based on the comparison with the Australian consultations [40], information about lifestyle risk factors in the national guidelines seems to be a prerequisite for having this information covered. And even given the inclusion of lifestyle in the Australian guideline, Australian counsellors and medical specialists $(n=17)$ felt that there was lack of evidence regarding the influence of lifestyle factors on BC risk and on the inter- action between genetic risk factors and lifestyle behaviours on the risk of BC [34]. Similarly, the Dutch genetic counsellors and clinical geneticists of the department of the current research seemed to be unaware of the evidence for a relation between lifestyle and BC [46]. Thus, inclusion of recent evidence for a relation between lifestyle and $\mathrm{BC}$ in the guideline and training of counsellors in the latest evi- dence could increase the frequency of lifestyle discussion.

\section{[TABLE 4] [TABLE 5]}


Albada, A., Vernooij, M., Osch, L. van, Pijpe, A., Dulmen, S. van, Ausems, M.G.E.M. Does and should breast cancer genetic counselling include lifestyle advice? Familial Cancer: 2014, 13(1), ) 35-44

This is the first study that videotaped and coded the communication of lifestyle risk factors in the first and final consultations of BC genetic counselling. Other studies about lifestyle discussion were based on focus groups with counselees [2] or counsellors [34] or were limited to recordings of only the first consultations [40]. One of the limitations of our study is that it only involved one clinical genetic centre. However, as all clinical genetic centres in the Netherlands follow the Dutch BC guideline [5, 32], no substantial differences between centres are expected. Secondly, causal attributions were only assessed with BC affected counselees because the illness perception questionnaire focuses on the patient's own illness. Future research should assess how unaffected counselees perceive the relationship between risk factors and BC. Also, the use of oral contraceptives and physical activity were not included in the widely used illness perception questionnaire [37], but should be included in future research. Finally, associations between whether the counsellor had given lifestyle advice and counselee characteristics could not be explored because of the low frequency of advices.

Based on the results of our study we recommend a debate amongst clinical geneticists and genetic counsellors on how to best incorporate information on lifestyle factors in BC genetic counselling. This advice applies to countries where lifestyle counselling is not included in guidelines, such as the Netherlands, but also to countries where guidelines include the recommendation to provide lifestyle risk information, but practice shows otherwise, such as Australia [40]. As the majority of counselees have high expectations to be told how to prevent BC $[3,4]$ and the success of genetic counselling depends on the accuracy to meet counselees' expectations [47, 48], it seems important to discuss protective lifestyle behaviours. Our recommendation is for counsellors to provide lifestyle information preferably with all counselees. Lifestyle advice should be provided if counselees feel the need for something to do in the hope of reducing their risk. It is also an opportunity to clarify that the influence of lifestyle factors are relatively small and are not the sole contributor of developing BC in an individual. This may alleviate feelings of guilt for one's own disease. However, if a counselee is already over- whelmed with the amount of genetics information [45] adding the lifestyle topic might not be appropriate or could be postponed to the follow-up consultation.

Before national guidelines can be updated to prescribe when to raise the topic of lifestyle, further research is needed to clarify how lifestyle information could be best integrated in BC genetic counselling. While holding on to the core values of providing balanced information and refraining from imposing values [49], information about the impact of modifiable lifestyle factors could be given to counselees to decide whether they would consider changing aspects of their lifestyle. We suggest that motivational interviewing techniques could be used to explore counselees' attitudes towards a healthy lifestyle and to discuss whether the counselee is ready to change her health behaviour. Motivational interviewing aims to help counselees to explore and resolve ambivalence between their attitudes, intentions and behaviour while promoting the autonomy of decision making [50]. Therefore, these techniques might be useful for genetic counselling to discuss lifestyle risk factors in a nondirective and counselee centred manner. Further study should show whether a training for counsellors in these skills indeed provides them with sufficient tools to discuss lifestyle. 
Albada, A., Vernooij, M., Osch, L. van, Pijpe, A., Dulmen, S. van, Ausems, M.G.E.M. Does and should breast cancer genetic counselling include lifestyle advice? Familial Cancer: 2014, 13(1), ) 35-44

\section{Acknowledgments}

We would like to thank Michelle Lenkens, Bianca Wiering and Melissa Gultzow for coding the consultations. Also, we would like to thank all counselees and genetic counsellors, clinical geneticists and residents in clinical genetics who participated in this study. This study was funded by a grant from the Dutch Cancer Society (Nivel 2010-4875).

\section{Conflict of interest}

The authors declare that they have no conflict of interest.

\section{REFERENCES}

1. Van Asperen CJ, Van Dijk S, Zoeteweij MW, Timmermans DR, De Bock GH, MeijersHeijboer EJ, Niermeijer MF, Breuning MH, Kievit J, Otten W (2002) What do women really want to know? Motives for attending familial breast cancer clinics. J Med Genet 39:410414

2. Rees G, Gaff C, Young MA, Martin PR (2007) Health beliefs and behaviors of women who have received genetic counseling for breast cancer. J Genet Couns 16:457-468

3. Lobb E, Butow P, Meiser B, Barratt A, Kirk J, Gattas M, Haan E, Tucker K (2002) The use of audiotapes in consultations with women from high risk breast cancer families: a randomised trial. J Med Genet 39:697-703

4. Lobb EA, Butow PN, Meiser B, Barratt A, Gaff C, Young MA,

Kirk J, Suthers GK, Tucker K (2002) Tailoring communication in consultations with women from high risk breast cancer families. Br J Cancer 87:502-508

5. NABON (The Netherlands National Breast Cancer Assembly) (2012) Breast cancer guideline. [Richtlijn Mammacarcinoom]. www.oncoline.nl/mammacarcinoom. Accessed 9 Feb 2013

6. Sasco AJ, Kaaks R, Little RE (2003) Breast cancer: occurrence, risk factors and hormone metabolism. Expert Rev Anticancer Ther 3:546-562

7. Pharoah PD, Day NE, Duffy S, Easton DF, Ponder BA (1997) Family history and the risk of breast cancer: a systematic review and meta-analysis. Int J Cancer 71:800-809

8. Easton DF, Pooley KA, Dunning AM, Pharoah PD, Thompson D, Ballinger DG, Struewing JP, Morrison J, Field H, Luben R, Wareham N, Ahmed S, Healey CS, Bowman R, SEARCH Col- laborators, Meyer KB, Haiman CA, Kolonel LK, Henderson BE, Le Marchand L, Brennan P, Sangrajrang S, Gaborieau V, Odefrey F, Shen CY, Wu PE, Wang HC, Eccles D, Evans DG, Peto J, Fletcher O, Johnson N, Seal S, Stratton MR, Rahman N, Chenevix- Trench G, Bojesen SE, Nordestgaard BG, Axelsson CK, Garcia- Closas M, Brinton L, Chanock S, Lissowska J, Peplonska B, Nevanlinna H et al (2007) Genome-wide association study iden- tifies novel breast cancer susceptibility loci. Nature 447:1087-1093

9. Parkin DM, Boyd L, Walker LC (2011) The fraction of cancer attributable to lifestyle and environmental factors in the UK in 2010. Br J Cancer 105:S77-S81

10. World Cancer Research Fund/American Institute for Cancer Research (2007) Food, nutrition, physical activity, and the pre- vention of cancer: a global perspective. AICR: Washington DC. http://eprints.ucl.ac.uk/4841/1/4841.pdf

11. Wu Y, Zhang D, Kang S (2013) Physical activity and risk of breast cancer: a metaanalysis of prospective studies. Breast Cancer Res Treat 137(3):869-882

12. International Agency for Research on Cancer (IARC) (2002) IARC Handbooks of cancer prevention: Volume 6: Weight con- trol and physical activity. IARC Press, Lyon. http://www.iarc.fr/ en/publications/pdfs-online/prev/handbook6/Handbook6-5.pdf

13. Monninkhof EM, Elias SG, Vlems FA, van DT I, Schuit AJ, Voskuil DW, van Leeuwen FE (2007) Physical activity and breast cancer: a systematic review. Epidemiology 18:137-157

14. Gonzalez CA, Riboli E (2010) Diet and cancer prevention: con- tributions from the European prospective investigation into cancer and nutrition (EPIC) study. Eur J Cancer 46: 2555-2562 
Albada, A., Vernooij, M., Osch, L. van, Pijpe, A., Dulmen, S. van, Ausems, M.G.E.M. Does and should breast cancer genetic counselling include lifestyle advice? Familial Cancer: 2014, 13(1), 35-44

15. Nelson HD, Zakher B, Cantor A, Fu R, Griffin J, O'Meara ES, Buist DS, Kerlikowske K, van Ravesteyn NT, Trentham-Dietz A, Mandelblatt JS, Miglioretti DL (2012) Risk factors for breast cancer for women aged 40-49 years: a systematic review and meta-analysis. Ann Intern Med 156:635-648

16. Hamajima N, Hirose K, Tajima K, Rohan T, Calle EE, Heath CW Jr, Coates RJ, Liff JM, Talamini R, Chantarakul N, Koetsawang S, Rachawat D, Morabia A, Schuman L, Stewart W, Szklo M, Bain C, Schofield F, Siskind V, Band P, Coldman AJ, Gallagher RP, Hislop TG, Yang P, Kolonel LM, Nomura AM, Hu J, Johnson KC, Mao Y, De Sanjose' S, Lee N, Marchbanks P, Ory HW, Peterson HB, Wilson HG, Wingo PA, Ebeling K, Kunde D, Nishan P, Hopper JL, Colditz G, Gajalanski V, Martin N, Pard- thaisong T, Silpisornkosol S, Theetranont C, Boosiri B, Chut- ivongse S, Jimakorn $P$, Virutamasen $P$, Wongsrichanalai C, Ewertz M, Adami HO, Bergkvist L, Magnusson C, Persson I, Chang-Claude J, Paul C, Skegg DC, Spears GF, Boyle P et al (2002) Alcohol, tobacco and breast cancercollaborative reanalysis of individual data from 53 epidemiological studies, including 58,515 women with breast cancer and 95,067 women without the disease. Br J Cancer 87:12341245

17. Collaborative Group on Hormonal Factors in breast cancer (2002) Breast cancer and breastfeeding: collaborative reanalysis of individual data from 47 epidemiological studies in 30 countries, including 50,302 women with breast cancer and 96,973 women without the disease. Lancet 360:187-195

18. McIntosh A, Shaw C, Evans G, Turnbull N, Bahar N, Barclay M, Easton D, Emery J, Gray J, Halpin J, Hopwood P, McKay J, Sheppard C, Sibbering M, Watson W, Wailoo A, Hutchinson A (2004) Clinical guidelines and evidence review for the classifi- cation and care of women at risk of familial breast cancer.

http://www.nice.org.uk/nicemedia/live/10994/30253/30253.pdf. Accessed 01 Nov 2012

19. King MC, Marks JH, Mandell JB (2003) Breast and ovarian cancer risks due to inherited mutations in BRCA1 and BRCA2. Science 302:643-646

20. Brohet RM, Goldgar DE, Easton DF, Antoniou AC, Andrieu N, Chang-Claude J, Peock S, Eeles RA, Cook M, Chu C, Nogues C, Lasset C, Berthet P, Meijers-Heijboer H, Gerdes AM, Olsson H, Caldes T, van Leeuwen FE, Rookus MA (2007) Oral contra- ceptives and breast cancer risk in the international BRCA1/2 carrier cohort study: a report from EMBRACE, GENEPSO, GEO-HEBON, and the IBCCS collaborating group. J Clin Oncol 25:3831-3836

21. Jernstrom H, Lubinski J, Lynch HT, Ghadirian P, Neuhausen S, Isaacs C, Weber BL, Horsman D, Rosen B, Foulkes WD, Friedman E, Gershoni-Baruch R, Ainsworth P, Daly M, Garber J, Olsson H, Sun P, Narod SA (2004) Breast-feeding and the risk of breast cancer in BRCA1 and BRCA2 mutation carriers. J Natl Cancer Inst 96:1094-1098

22. Pijpe A, Manders P, Brohet RM, Collee JM, Verhoef S, Vasen HF, Hoogerbrugge N, van Asperen CJ, Dommering C, Ausems MG, Aalfs CM, Gomez-Garcia EB, Van't Veer LJ, van Leeuwen FE, Rookus MA (2010) Physical activity and the risk of breast cancer in BRCA1/2 mutation carriers. Breast Cancer Res Treat 120:235-244

23. Moorman PG, Iversen ES, Marcom PK, Marks JR, Wang F, Lee E, Ursin G, Rebbeck TR, Domchek SM, Arun B, Susswein L, Isaacs C, Garber JE, Visvanathan K, Griffin CA, Sutphen R, Brzosowicz J, Gruber S, Finkelstein DM, Schildkraut JM (2010) Evaluation of established breast cancer risk factors as modifiers of BRCA1 or BRCA2: a multi-center case-only analysis. Breast Cancer Res Treat 124:441-451

24. Nkondjock A, Robidoux A, Paredes Y, Narod SA, Ghadirian P (2006) Diet, lifestyle and BRCA-related breast cancer risk among French-Canadians. Breast Cancer Res Treat 98:285-294

25. Manders P, Pijpe A, Hooning MJ, Kluijt I, Vasen HF, Hoo- gerbrugge N, van Asperen CJ, Meijers-Heijboer H, Ausems MG, van Os TA, Gomez-Garcia EB, Brohet RM, van Leeuwen FE, Rookus MA (2011) Body weight and risk of breast cancer in BRCA1/2 mutation carriers. Breast Cancer Res Treat 126:193-202

26. Lemon SC, Zapka JG, Clemow L (2004) Health behavior change among women with recent familial diagnosis of breast cancer. Prev Med 39:253-262

27. Appleton S, Fry A, Rees G, Rush R, Cull A (2000) Psychosocial effects of living with an increased risk of breast cancer: an exploratory study using telephone focus groups.

Psychooncology 9:511-521 
Albada, A., Vernooij, M., Osch, L. van, Pijpe, A., Dulmen, S. van, Ausems, M.G.E.M. Does and should breast cancer genetic counselling include lifestyle advice? Familial Cancer: 2014, 13(1), ) 35-44

28. Biesecker BB (1998) Future directions in genetic counseling: prac- tical and ethical considerations. Kennedy Inst Ethics J 8:145-160

29. NICE (2006) Clinical guideline 14. Familial breast cancer. The classification and care of women at risk of familial breast cancer in primary, secondary and tertiary care. http://www.nice.org.uk/ nicemedia/pdf/cg41niceguidance.pdf. Accessed 01 Nov 2012

30. NCCN (National Comprehensive Cancer Network) (2012) Breast cancer risk reduction. Clinical guidelines in oncology version 1 http://www.nccn.org/professionals/physician_gls/PDF/breast_risk. pdf. Accessed 01 Nov 2012

31. National Breast and Ovarian Cancer Centre (2010) Advice about familial aspects of breast cancer and epithelial ovarian cancer, a guide for health professionals. http://canceraustralia.gov.au/sites/ default/files/publications/nbocc-bog-2010-web-a4printable_ 504af02a673fd.pdf. Accessed 04 Feb 2013

32. Association of Clinical Genetics Netherlands (VKGN) (2010) Hereditary breast and ovarian cancer guideline. [Richtlijn Hered- itair mamma/ovarium carcinoom]. www.oncoline.nl/hereditair- mamma-ovariumcarcinoom. Accessed 9 Feb 2013

33. Julian-Reynier CJ, Eisinger F, Chabal F, Aurran Y, Bignon YJ, Nogue`s C, MachelardRoumagnac M, Maugard C, Vennin P, Sobol H (1998) Cancer genetic clinics: why do women who already have cancer attend? Eur J Cancer 34:1549-1553

34. Rees G, Young MA, Gaff C, Martin PR (2006) A qualitative study of health professionals views regarding provision of information about health-protective behaviors during genetic consultation for breast cancer. J Genet Couns 15:95-104

35. Albada A, Van Dulmen S, Lindhout D, Bensing J, Ausems M (2012) A pre-visit tailored website enhances counselees' realistic expectations and knowledge and fulfils information needs for breast cancer genetic counseling. Fam Cancer 11:85-95

36. Roter D (2006) The Roter method of interaction process analysis. Johns Hopkins School of Public Health, Baltimore

37. Moss-Morris R, Weinman J, Petrie K, Horne R, Cameron L, Buick D (2002) The revised illness perception questionnaire (IPQ-R). Psychol Health 17:1-16

38. Van Oostrom I, Meijers-Heijboer H, Duivenvoorden HJ, Bröcker-Vriends AH, van Asperen CJ, Sijmons RH, Seynaeve C, Van Gool AR, Klijn JG, Tibben A (2007) Comparison of individuals opting for BRCA1/2 or HNPCC genetic susceptibility testing with regard to coping, illness perceptions, illness experiences, family system characteristics and hereditary cancer distress. Patient Educ Couns 65(1):58-68

39. Van Asperen CJ, Jonker MA, Jacobi CE, Van Diemen-Homan JE, Bakker E, Breuning $\mathrm{MH}$, Van Houwelingen JC, de Bock GH (2004) Risk estimation for healthy women from breast cancer families: new insights and new strategies. Cancer Epidemiol Biomarkers Prev 13:87-93

40. Butow P, Lobb E (2004) Analyzing the process and content of genetic counseling in familial breast cancer consultations. J Genet Couns 13:403-424

41. Meiser B, Irle J, Lobb E, Barlow-Stewart K (2008) Assessment of the content and process of genetic counseling: a critical review of empirical studies. J Genet Couns 17:434-451

42. Pieterse AH, Van Dulmen AM, Ausems MGEM, Beemer FA, Bensing JM (2005) Communication in cancer genetic counsel- ling: does it reflect counselees' pre-visit needs and preferences? Br J Cancer 92:1671-1678

43. Ellington L, Roter D, Dudley WN, Baty BJ, Upchurch R, Larson S, Wylie JE, Smith KR, Botkin JR (2005) Communication analysis of BRCA1 genetic counseling. J Genet Couns 14:377-386

44. Ellington L, Baty BJ, McDonald J, Venne V, Musters A, Roter D, Dudley W, Croyle RT (2006) Exploring genetic counseling communication patterns: the role of teaching and counseling approaches. J Genet Couns 15:179-189

45. Ellington L, Maxwel A, Baty BJ, Roter D, Dudley WN, Kinney AY (2007) Genetic counseling communication with an African American BRCA1 kindred. Soc Sci Med 64:724734

46. Kolsteren J (2010) Lifestyle factors: an item during breast cancer genetic counselling? Experiences and opinions of professionals. Unpublished thesis, University Medical Center Utrecht 
Albada, A., Vernooij, M., Osch, L. van, Pijpe, A., Dulmen, S. van, Ausems, M.G.E.M. Does and should breast cancer genetic counselling include lifestyle advice? Familial Cancer: 2014, 13(1), 35-44

47. Pieterse AH, Ausems MGEM, Van Dulmen AM, Beemer FA, Bensing JM (2005) Initial cancer genetic counseling consultation: change in counselees' cognitions and anxiety, and association with addressing their needs and preferences. Am J Med Genet A 137:27-35

48. Michie S, Marteau TM, Bobrow M (1997) Genetic counselling: the psychological impact of meeting patients' expectations. J Med Genet 34:227-241

49. Weil J (2003) Psychosocial genetic counseling in the post-non- directive era: a point of view. J Genet Couns 12:199-211

50. Rollnick S, Butler CC, Kinnersley P, Gregory J, Mash B (2010) Motivational interviewing. BMJ 340:c1900

\section{TABLES}

Table 1 Counselee characteristics $(\mathrm{N}=192)$

\begin{tabular}{|c|c|c|c|c|}
\hline Mean & & SD & & Range \\
\hline \multirow[t]{2}{*}{ Age (years) } & \multicolumn{3}{|c|}{11.4} & $21-69$ \\
\hline & \multicolumn{3}{|c|}{$\mathrm{N}$} & $\%$ \\
\hline \multicolumn{2}{|l|}{ Counselees having children } & \multicolumn{2}{|l|}{132} & 68.8 \\
\hline \multicolumn{5}{|l|}{ Educational attainment ${ }^{\mathrm{a}}$} \\
\hline \multicolumn{2}{|l|}{ Higher vocational education (BSc)/University (MSc/BSc) } & \multicolumn{2}{|l|}{77} & 41.6 \\
\hline \multicolumn{2}{|l|}{$<$ High school through middle vocational education } & \multicolumn{2}{|l|}{108} & 58.4 \\
\hline \multicolumn{5}{|l|}{ Referral pathway } \\
\hline General practitioner & & \multicolumn{2}{|l|}{98} & 51.0 \\
\hline Specialist consultant & & \multicolumn{2}{|l|}{94} & 49.0 \\
\hline \multicolumn{2}{|l|}{ Personal history of BC (affected) } & \multicolumn{2}{|l|}{78} & 40.6 \\
\hline \multicolumn{2}{|l|}{ Indication for DNA-testing for counselee or affected relative } & \multicolumn{2}{|l|}{151} & 78.7 \\
\hline \multicolumn{2}{|l|}{ DNA-test uptake } & \multicolumn{2}{|l|}{84} & 55.6 \\
\hline \multicolumn{5}{|l|}{ BRCA1/2-test result ${ }^{\mathrm{b}}$} \\
\hline \multicolumn{2}{|l|}{ Uninformative test result ${ }^{c}$} & \multicolumn{2}{|l|}{68} & 35.4 \\
\hline \multicolumn{2}{|l|}{ BRCA1/2 mutation carrier } & \multicolumn{2}{|l|}{7} & 3.7 \\
\hline \multicolumn{2}{|l|}{$50 \%$ risk of being a BRCA $1 / 2$ mutation carrier ${ }^{d}$} & \multicolumn{2}{|l|}{3} & 1.6 \\
\hline \multicolumn{2}{|l|}{ Variant of unexplained clinical significance (VUCS) } & \multicolumn{2}{|l|}{7} & 3.7 \\
\hline & Mean \% & & SD & Range \\
\hline \multicolumn{5}{|l|}{ Risk estimation by counsellor $(0-100 \%)^{\mathrm{e}}$} \\
\hline \multicolumn{5}{|l|}{ Unaffected counselees $(n=114)$} \\
\hline Lifetime BC risk for counselee & 18.4 & & 6.8 & $5-38$ \\
\hline \multicolumn{5}{|l|}{ Affected counselees $(n=78)$} \\
\hline Lifetime $\mathrm{BC}$ risk for female first degree relatives & 20.9 & & 10.6 & $10-70$ \\
\hline
\end{tabular}

$B C$ breast cancer

a Seven missing values

b Total counts 85 instead of the 84 counselees with test uptake as one test result indicated a BRCA1/2-mutation as well as a VUCS

c No BRCA1/2 mutation detected

d Breast cancer unaffected counselees with a first degree relative who tested positive for a BRCA1/2 mutation

- Six missing values 
Albada, A., Vernooij, M., Osch, L. van, Pijpe, A., Dulmen, S. van, Ausems, M.G.E.M. Does and should breast cancer genetic counselling include lifestyle advice? Familial Cancer: 2014, 13(1), 35-44

Table 2 Frequency, initiative, and communication style of lifestyle discussion in breast cancer genetic counselling

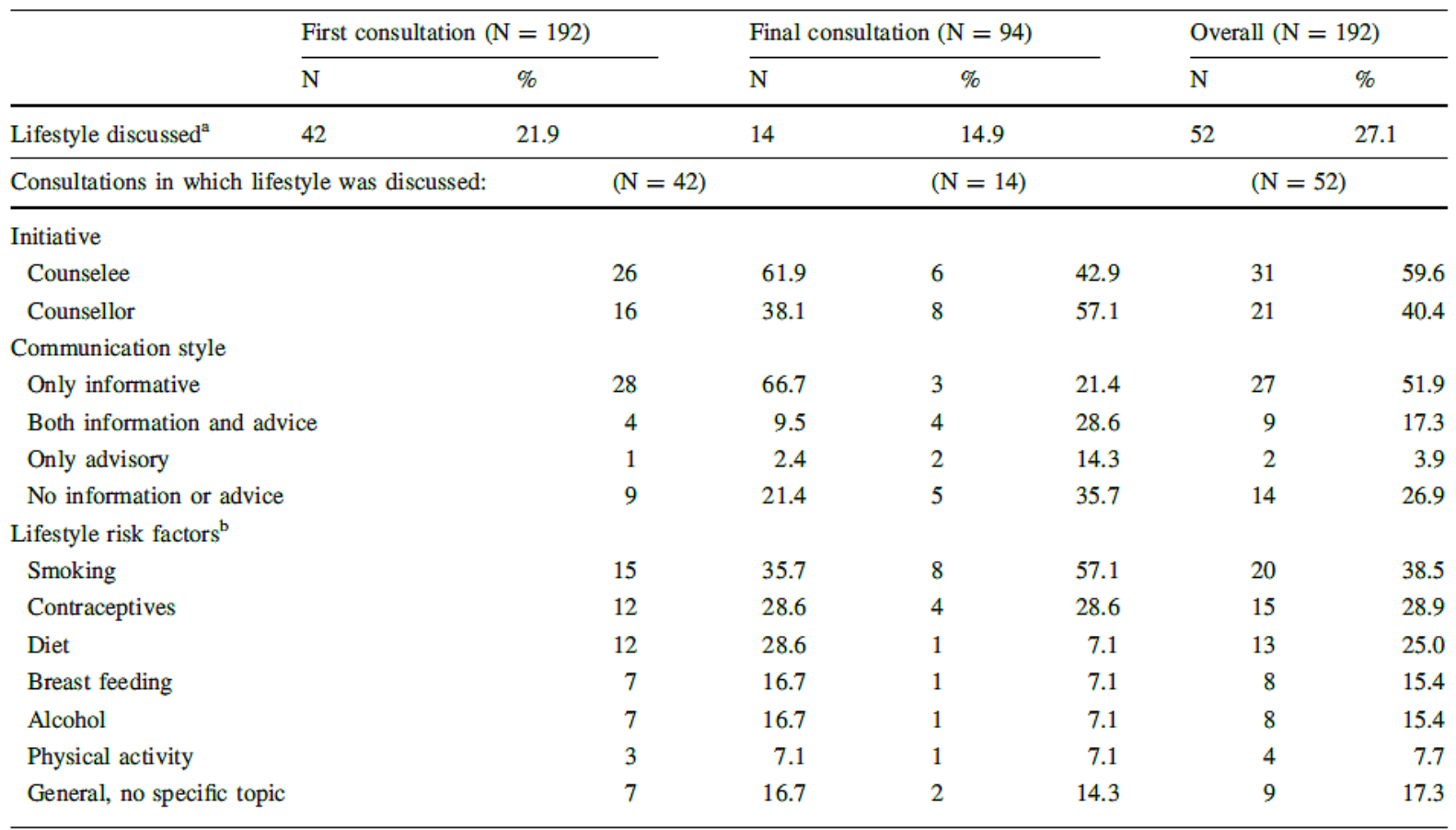

${ }^{a}$ Either one of the lifestyle factors smoking, diet, contraceptives, breast feeding, alcohol, physical activity or lifestyle in general

${ }^{\mathrm{b}}$ More than one factor can be discussed in a consultation

Table 3 Results of multilevel logistic regression on determinants of lifestyle discussion (yes vs. no) in the (initial and final follow-up) consultations with unaffected and affected counselees

\begin{tabular}{|c|c|c|c|c|c|c|}
\hline & \multicolumn{3}{|c|}{$\begin{array}{l}\text { Unaffected counselees } \\
(\mathrm{N}=109)\end{array}$} & \multicolumn{3}{|c|}{$\begin{array}{l}\text { Affected counselees } \\
(\mathrm{N}=74)\end{array}$} \\
\hline & OR & $\mathrm{SE}$ & $p$ & OR & $\mathrm{SE}$ & $p$ \\
\hline Age & 1.02 & 0.03 & 0.40 & 1.00 & 0.03 & 0.87 \\
\hline Having children $($ no $=$ ref) & 1.07 & 0.58 & 0.90 & 2.51 & 2.33 & 0.32 \\
\hline Education (less than BSc. $=$ ref) & 0.90 & 0.43 & 0.83 & 0.69 & 0.41 & 0.53 \\
\hline Lifetime BC risk for counselee (for unaffected) or for female FDR (affected counselees) & 0.98 & 0.04 & 0.53 & 1.00 & 0.03 & 0.87 \\
\hline Indication for DNA-testing in family ( $\mathrm{no}=$ ref) & 1.59 & 0.93 & 0.42 & 0.32 & 0.25 & 0.15 \\
\hline Lifestyle as a cause of BC at baseline (disagree/no opinion $=$ ref) & - & - & - & 2.16 & 1.66 & 0.32 \\
\hline Heredity as a cause of $\mathrm{BC}$ at baseline (disagree/no opinion $=$ ref) & - & - & - & 0.54 & 0.41 & 0.42 \\
\hline
\end{tabular}

Not all 114 unaffected counselees and 78 affected counselees could be included in the analyses due to missing values on education, lifetime BC risk and the causal attributions

$B C$ breast cancer, $F D R$ first degree relative, $O R$ Odds ratio, $S E$ standard error 
Albada, A., Vernooij, M., Osch, L. van, Pijpe, A., Dulmen, S. van, Ausems, M.G.E.M. Does and should breast cancer genetic counselling include lifestyle advice? Familial Cancer: 2014, 13(1), 35-44

Table 4 Causal attributions of affected counselees

\begin{tabular}{|c|c|c|c|c|}
\hline \multirow[t]{2}{*}{ Affected counselees ${ }^{c}$} & \multicolumn{2}{|c|}{ Pre-counselling $(\mathrm{N}=74)^{\mathrm{a}}$} & \multicolumn{2}{|c|}{ Post-counselling $(\mathrm{N}=59)^{\mathrm{b}}$} \\
\hline & $\mathrm{N}$ & $\%$ & $\mathrm{~N}$ & $\%$ \\
\hline Hereditary factors & 14 & 18.9 & 8 & 13.6 \\
\hline Sum lifestyle factors (diet, alcohol, smoking) ${ }^{\mathrm{d}}$ & 11 & 14.9 & 17 & $28.8 *$ \\
\hline Diet & 9 & 12.3 & 9 & 15.3 \\
\hline Alcohol & 3 & 4.1 & 4 & 6.8 \\
\hline Smoking & 4 & 5.4 & 8 & 13.6 \\
\hline \multirow[t]{2}{*}{ BRCA1/2 mutation carriers $^{c}$} & \multicolumn{2}{|c|}{ Pre-counselling $(\mathrm{N}=7)$} & \multicolumn{2}{|c|}{ Post-counselling $(\mathrm{N}=6)^{\mathrm{f}}$} \\
\hline & $\mathrm{N}$ & $\%$ & $\mathrm{~N}$ & $\%$ \\
\hline Hereditary factors & 2 & - & 6 & - \\
\hline Sum lifestyle factors (diet, alcohol, smoking) ${ }^{\mathrm{d}}$ & 3 & - & 3 & - \\
\hline Diet & 3 & - & 1 & - \\
\hline Alcohol & 1 & - & 1 & - \\
\hline Smoking & 1 & - & 2 & - \\
\hline
\end{tabular}

a Four missing values

b 19 missing values

c Including the seven BRCA1/2 mutation carriers

${ }^{d}$ Diet, alcohol and smoking do not add up to the sum lifestyle factors as more than one factor could be seen as a cause. Use of oral contraceptives and physical activity were not included in the Revised Ilness Perception Questionnaire and causal attributions concerning these lifestyle factors were therefore not assessed

${ }^{c}$ No percentages given because of small numbers of counselees

${ }^{\mathrm{f}}$ One missing value

$* p<0.05$

Table 5 Results of multilevel logistic regression on whether lifestyle risk factors were seen as cause of breast cancer post-counselling by affected counselees $(\mathrm{N}=57)$

\begin{tabular}{|c|c|c|c|c|c|c|}
\hline & \multirow{2}{*}{\multicolumn{3}{|c|}{$\begin{array}{l}\text { Lifestyle as a cause of breast } \\
\text { cancer } \\
\text { Post-counselling }\end{array}$}} & \multirow{2}{*}{\multicolumn{3}{|c|}{$\begin{array}{l}\text { Heredity as a cause of breast } \\
\text { cancer } \\
\text { Post-counselling }\end{array}$}} \\
\hline & & & & & & \\
\hline & OR & SE & $p$ & OR & SE & $p$ \\
\hline Lifestyle as a cause of $\mathrm{BC}$ pre-counselling (disagree/no opinion $=$ ref) & 8.49 & 6.89 & 0.01 & - & - & - \\
\hline Heredity as a cause of BC pre-counselling (disagree/no opinion $=$ ref) & - & - & - & 11.68 & 14.81 & 0.05 \\
\hline Lifetime $\mathrm{BC}$ risk for female FDR & 1.03 & 0.04 & 0.51 & 1.30 & 0.13 & 0.01 \\
\hline Discussion of lifestyle during counselling (no $=$ ref) & 0.73 & 0.54 & 0.67 & 0.16 & 0.23 & 0.20 \\
\hline
\end{tabular}

Not all 78 affected counselees could be included in the analyses due to missing values on the causal attributions at pre and post-counselling $B C$ breast cancer, $F D R$ first degree relative, $O R$ Odds ratio, $S E$ standard error

Bold numbers show statistical significant results 